\title{
ADVANCED LIQUID METAL REACTOR SITE SELECTION CRITERIA REPORT
}

\author{
R. L. Sivill
}

January 1990
Prepared for the Nuclear Energy Division of
the Generat Electric Company, Inc.
by
EG\&G Idaho, Inc.
Idaho National Engineering Laboratory
Idaho Falls, Idaho 83415 DISCLAIMER
This document is
PUBLICLY RELEASABLE
BStecle
Authorizing Official
Date: - $6 / 16 / 06$

This report was prepared as an account of work sponsored by an agency of the United States Government. Neither the United States Government nor any agency thereof, nor any of their employees, makes any warranty, express or implied, or assumes any legal liability or responsibility for the accuracy, completeness, or usefulness of any information, apparatus, product, or process disclosed, or represents that its use would not infringe privately owned rights. Reference herein to any specific commercial product, process, or service by trade name, trademark, manufacturer, or otherwise does not necessarily constitute or imply its endorsement, recommendation, or favoring by the United States Government or any agency thereof. The views and opinions of authors expressed herein do not necessarily state or reflect those of the United States Government or any agency thereof. 


\section{DISCLAIMER}

This report was prepared as an account of work sponsored by an agency of the United States Government. Neither the United States Government nor any agency Thereof, nor any of their employees, makes any warranty, express or implied, or assumes any legal liability or responsibility for the accuracy, completeness, or usefulness of any information, apparatus, product, or process disclosed, or represents that its use would not infringe privately owned rights. Reference herein to any specific commercial product, process, or service by trade name, trademark, manufacturer, or otherwise does not necessarily constitute or imply its endorsement, recommendation, or favoring by the United States Government or any agency thereof. The views and opinions of authors expressed herein do not necessarily state or reflect those of the United States Government or any agency thereof. 


\section{DISCLAIMER}

Portions of this document may be illegible in electronic image products. Images are produced from the best available original document. 


\section{ADVANCED LIQUID METAL REACTOR SITE SELECTION CRITERIA REPORT}

\section{PURPOSE AND BACKGROUND}

General Electric (GE)

initiated and developed the concept of the Power Reactor Innovative Small Module (PRISM) liquid metal cooled reactor in the 1980s. The intent was to develop a low cost, demonstrably safe, reliable, electrical power generator.

In 1988, the U. S. Department of Energy (DOE) selected the PRISM concept as the basis for the Advanced Liquid Metal Reactor (ALMR) Program. The reactor design is referred to as the ALMR throughout this document. The reference commercial power plant of this design is made up of nine identical reactor/steam generator modules, grouped into three power blocks of three reactor/steam generator modules each. There is one turbinegenerator for each power block, capable of generating 465 MWe. The reactor and steam generator modules are to be factory fabricated and delivered to a prepared site. Bechtel National, Inc. is currently the nuclear island architectengineer for GE. The program plan is to seek standard design certification from the U. S. Nuclear Regulatory Commission (NRC) for the commercial version of this design. It is planned to construct one completely prototypical reactor module at a DOE site, and perform the safety tests required to support standard design certification. It is then planned to add a steam generator module and turbinegenerator in order to demonstrate the power producing capability of the design over an extended period of time, and to recover the majority of the investment by selling power produced. An option is to add equipment for a full power block.

Some preliminary site assessments were performed in 1986 and 1987 for the prototype test, primarily looking at the economics of using existing facilities at various potential sites for performance of the safety tests on one reactor module. In 1989, the New Programs Department of EG\&G 
Idaho was asked to develop the methodology and criteria for a more

rigorous site selection process, expanding the scope of interest from the original economics for a one reactor module safety test to also include National Environmental Policy Act (NEPA) considerations, NRC siting regulations, ALMR design requirements, and the addition of a steam generator module and turbinegenerator for the power producing phase. The methodology and criteria were to be developed for use at any potential DOE site. EG\&G Idaho was al so requested to perform a pilot study at the Idaho National Engineering Laboratory (INEL) using the newly developed methodology and criteria. This study was for instructional purposes only; DOE will make the final determination on site selection.

\section{SITE SELECTION}

\section{Organization}

A committee was formed at the INEL to develop site selection criteria, conduct evaluation, and select suitable sites for the ALMR on the INEL. Representatives from Argonne National Laboratory-West (ANL-W), Department of Energy-Idaho Operations (DOE-ID), EG\&G Idaho, and General Electric Nuclear Energy (GE) were organized to develop the criteria and methodology. The participants are listed below.

CRITERIA AND METHODOLOGY COMMITTEE MEMBERS
E. W. Krenz
ANL-W
C. Noble
DOE-ID
R. W. Hardy
GE
R. L. Sivill, EG\&G Idaho
Chairperson

\section{ADVISORS}
P. I. Amundson
ANL - W
D. W. Constable
EG\&G Idaho
T. J. Hill
EG\&G Idaho
S. M. Modro
EG\&G Idaho

After the committee generated the criteria and methodology, representatives from the National Oceanic Atmospheric Administration (NOAA), ANL-W and EG\&G Idaho formed a field team to perform the pilot study.

\section{EIELD TEAM}
G. E. Start
NOAA
K. L. Clawson
NOAA
P. I. Amundson
ANL - W 
J. T. Barraclough

Hydrology

P. J. Hill

Cost Estimation

S. M. Jackson

Seismicity

G. A. Leuzinger

Facility Planning

T. N. Thiel

Facility Planning

S. M. Modro

Nuclear Reactor Research \& Tech.

N. K. Powell

Energy Management

J. F. Seward

Security

G. R. English

Security

R. L. Sivill

Project Management Service

and Chairperson

R. P. Smith

EG\&G Idaho

Geology/Volcanism

C. S. Staley

Environmental/Safety and Quality

\section{Approach}

The Methodology and Criteria Committee used a modified KepnerTrego Decision Analysis (K-T)

approach to develop criteria to be used in evaluating candidate sites. Selection criteria were separated into "Musts" and "Wants", based on NEPA considerations, NRC siting regulations, ALMR design requirements, economics, and a follow-on power producing phase.
Criteria recently developed by EG\&G for siting the New Production Reactor at INEL were considered in developing the final list.

"Musts" are those criteria considered to be necessary for site acceptability. Proposed sites that do not meet each and every one of the "Musts" requirements are to be eliminated from further consideration.

"Wants" are those criteria considered to be desirable for site acceptability. These criteria have a sliding scale of importance called "weighing factors" which range in value from a low of 1 to a high of 10. The committee assigned weighing factors to each "Want" criterion, based on the experience and judgement of each member of the committee and his "home" organization. Bechtel input was included as part of the GE "home" organization. Each organization developed a weighing factor for each "Want" criterion, and the committee then resolved the resulting four factors into one consensus whole integer weighing factor ranging from 1 to 10. A copy of the resulting weighted site selection criteria forms is included as an attachment to this report. 
The INEL Field Team then took the weighted site selection criteria and used them at INEL in the pilot study to evaluate potential INEL sites for the ALMR Prototype. Each team member was assigned specific criteria for review and evaluation of each available site at INEL, based on his or her areas of expertise. A requirement of documentation rigor, patterned after

NEPA requirements, was established.

The first step was to review potential sites against the "Musts", and make a first cut reduction. The two items which were most limiting were the earthquake and volcano criteria. The other "Musts" were less limiting.

The team then addressed the "Wants". For each criterion, and for each site passing the "Musts", the team developed a whole integer score on a scale from a low of 1 to a high of 10 . If a site did not meet a "Want" criterion, or have that specific attribute, the score was left blank. Each criterion's score was then multiplied by that criterion's weighing factor, and the weighted scores for all criteria added to obtain a total weighted score for each site. Based on total weighted scores, each site was then ranked.

The details of this process, and the results, are discussed in a separate report entitled "Pilot Site Selection Study for the Advanced Liquid Reactor at the Idaho National Engineering Laboratory".

\section{Site Selection Criteria}

The site selection criteria and the K/T Decision Analysis forms developed by the committee and used by the INEL Field Team are included as an attachment to this report. The same site selection methodology and criteria will be used to evaluate other possible DOE facilities. 
1. OBJECTIVES

A. Establish site selection process, priorities, magnitude, and constraints

B. Apply process to INEL to select a reference site for evaluation.

2. ASSUMPTIONS

A. Primary purpose of the ALMR Prototype is to perform a near term Safety Test to provide information to support Standard Design Certification. Secondary purpose is to operate during a long term Power Production Phase to demonstrate operability, maintainability, inspectability, availability, and to recover a significant portion of the investment.

B. Near Term Safety Test - one reactor module (including steam generator to bound possible requirements)

C. Long Term Power Production - full power block (three reactors, three steam generators, one

D. Government owned site

E. Fuel fabrication and reprocessing at Argonne National Laboratory - West (ANL-W)

- Near Term 1 reactor

- Long Term 3 reactors 
3. SITE SPECIFIC CRITERIA

A. Musts

1. Less than or equal to $0.3 \mathrm{~g}$ safe shutdown earthquake (ALMR design requirement)

2. Greater than 5 miles from capable fault (10 CFR 100, Appendix A, Part III defines capable fault)

3. Outside volcanic exclusionary zone (not defined in 10 CFR 100, but an acceptable definition is outside "recent" lava flows, at least 3 miles from "older" vents, and at least 5 miles from "recent" vents)

4. Above flood plain, both seismically induced and water runoff induce (10 CFR 100, Appendix A. For INEL, this must include above the Mackay Dam failure flood elevation)

5. Meet 10 CFR 100 population density requirements

6. Land Area

a. 18 level acres, approximately square and fenceable (ALMR) requirement)

b. 600 acres exclusion zone ( -0.5 mile around site boundary)

7. Acceptable meteorology, given any nearby existing structures (not defined in 10 CFR 100, but an acceptable definition must include meeting radiation limits at site boundary and downwind when plume interactions with nearby structures are included) 
3. SITE SPECIFIC CRITERIA (continued)

A. Musts

8. Meet environmental requirements

a. National Environmental Policy Act of 1969 (42 USC 4321-4347)

b. Endangered Species Act of 1973 (50 CFR 17.11)

c. Bald and Golden Eagle Protection Act (50 CFR 10.13.22)

d. Migratory Bird Treaty Act (16 USC 703)

9. Meet NRC Site Suitability Requirements in Regulatory Guide 4.7

10. Water from on-site wells (shallower wells are generally cheaper)
a. Near Term Safety Test
$-3,500 \mathrm{gpm}$
b. Long Term Power Production - 9,000 gpm

11. Suitable for long term power production and sales

a. Land

b. Transmission line accessibility and right of way

12. Availability

a. Initiation of formal NEPA process beginning in 1992, with on-site environmental studies including bore holes

b. Site preparatory work beginning in 1995, including access road construction, site leveling, and water well drilling 
3. SITE SPECIFIC CRITERIA (cont inued)

B. Wants

WEIGHT SCORE

WE IGHT

1. Near Term Safety Test (to minimize cost)

a. Use of existing facilities (1abs, maintenance shops, administration building, guard hose, warehouse, personnel building, fire protection, cafeteria)

b. Use of existing services (security, safeguards, quality assurance, health physics, buses, medical, communications)

c. Use of existing support in - sodium technology and operations

- operator training

- waste handling

- inspection and maintenance techniques

d. Ease of access to fuel cycle facility at ANL-W (for fuel fabrication and processing)

2. Long Term Power Production (to maximize plant availability)

a. Independent of off-site utilities (power and water) 8

b. Independent of the activities of others (minimize power plant shutdowns due to activities of others, and minimize interference of others due to power plant operation)

$\begin{array}{r}8 \\ \hline 8 \\ \hline\end{array}$


3. SITE SPECIFIC CRITERIA (cont inued)

B. Wants

c. Self-contained plant staff (including operations, security, safeguards, quality assurance, health physics)

d. Use of some existing infrastructure (buses, fire protection, medical where there is minimal interference with activities of others)

e. Support for training operators, and for developing maintenance and inspection techniques (including test labs, simulators, and equipment)

f. Ease of access to fuel cycle facility at ANL-W (for fuel fabrication and processing)

3. Auxiliary Power

a. Near Term Safety Test - 13 MWe (startup \& operation)

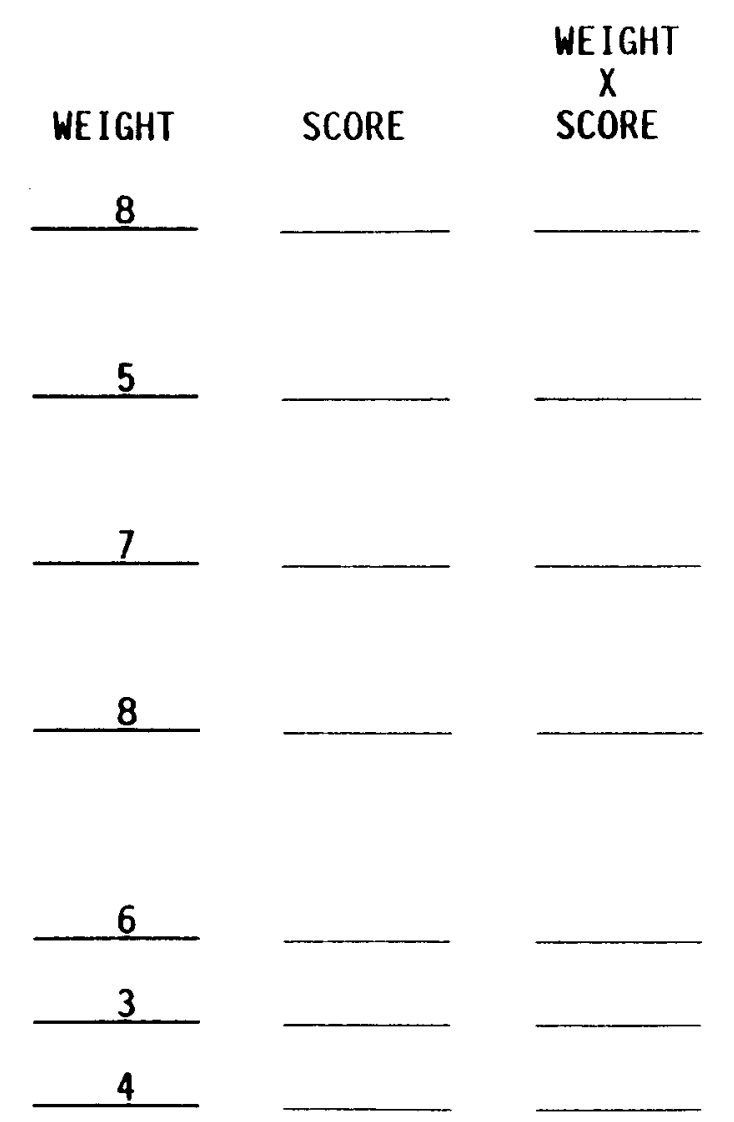

4. Telephone/Computer Communication Links 
3. SITE SPECIFIC CRITERIA (continued)

B. Wants

5. Radioactive Waste Disposal

a. Near Term Safety Test

(1) $30,000 \mathrm{gal} / \mathrm{yr}$ liquid (could be stored on-site)

(2) $400 \mathrm{ft}^{3} / \mathrm{yr}$ solid (could be stored on-site)

b. Long Term Power Production

(1) 70,000 gal/yr liquid (need off-site disposal)

(2) $1,000 \mathrm{ft}^{3} / \mathrm{yr}$ solid (need off-site disposal)

6. Nonradioactive Waste Disposal

a. Near Term Safety Test

(1) 5,000 gal/day sanitary (could be disposed on-site)

(2) $500 \mathrm{gpm}$ industrial

b. Long Term Power Production

5

(1) 10,000 gal/day sanitary (could be disposed on-site)

(2) $900 \mathrm{gpm}$ industrial 
3. SITE SPECIFIC CRITERIA (continued)

B. Wants

7. Meteorological services (to provide long term monitoring for environmental records

8. Access (for Near Term Safety Test)

a. Road (required for construction trucks and personnel)

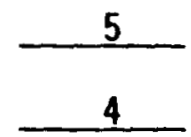

b. Railroad track (a railhead to the site, or close to the site, is desirable for module shipments)

c. Barge

9. Access (for Long Term Power Production)
a. Road (required for truck deliveries and personnel)
b. Railroad track
c. Barge

10. Electric utility/power company involvement (for constructing the turbine-generator facilities, for operating the whole plant, and for selling power)

\begin{tabular}{ccc} 
& & WEIGHT \\
& & $\underset{X}{\text { SCIGHT }}$ \\
4 & SCORE & \\
\hline
\end{tabular}
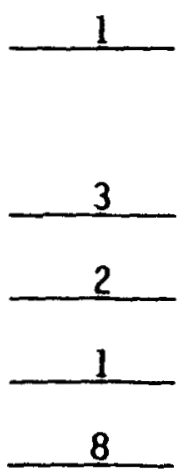